\title{
ACCEPTING AND COMPREHENDING CHRISTIANITY: NON-EUROPEAN PRACTICE OF THE RELIGION
}

In both Japan and New France, those whom the Jesuits would convert to Christianity interpreted Christianity and its practice in widely varying ways. What did the Jesuit preaching and Christianity mean to them in the context of their own native culture? What played the most influential rôle in formulating the actual practice of Christianity among converts? Above all, was there any divergence, between the European opinions and the non-European ideas, regarding the true meaning of becoming a Christian in a non-Christian realm? To answer these questions, some hypotheses can be explored about the practice of Christianity among Japanese converts. Such hypothetical perspectives will then be tested in examples of the Amerindian acceptance of the religion in New France.

\section{A. Problems of Historical Epistemology}

Traditionally histories of both regions have focussed on degrees of conversion into what is thought to be authentic Christianity. These historiographical debates are based on the premise that a person is either a true Christian or not, and that a non-Christian who does not completely accept Christian theology can never be called Christian. For example, Christal Whelan examines Japanese rituals and icons, and concludes that Japanese Christians were not at all genuinely converted. Referring to the converts in the missionary settlement of Caughnawaga, near Montreal, David Blanchard contends that Iroquoian neophytes interpreted Jesuit preaching within a traditional indigenous framework and thus failed to become true Christians. Notwithstanding different religious contexts, how much one accepts Christian thought and practice is a global subject rather than just a local issue peculiar to non-European converts. Furthermore, neither Whelan nor Blanchard explains that even in the Europe of the sixteenth century, Jesuits were struggling to convert Europeans 
from folk religions, Islam and Judaism to what Jesuits considered ideal Christianity. ${ }^{1}$

The two treatises of Whelan and Blanchard have unintentionally disclosed three problems of historical epistemology on non-European Christianity. First, they have become mired in a psychological interpretation influenced by personal religious understanding and piety, which leads them to inconclusive results. What the Jesuit missionaries themselves were concerned about was their converts' constancy of faith and of their support for priests, not the degree of resemblance to the European Christian belief. ${ }^{2}$ What seems of greater import to a discussion of nonEuropean Christianity should be how potential converts used their limited understanding of Christianity, based inevitably on non-Christian concepts, in order to grasp and practise this foreign spirituality so that it might serve their needs.

The second problem is how to judge the authenticity of conversion to Christianity on the part of non-Christians. Testing an individual's depth of belief, as both Whelan and Blanchard do, is a typical late-modern attitude, which developed gradually with the spread of Protestantism and its emphasis upon a personal relationship with God. Literate, educated urban residents in sixteenth- and seventeenth-century France favoured Protestantism. Previous to the Protestant Reformation, Christianity was ritual-based collectivism and not testament-based individualism. What the Jesuits fought against in France and the Iberian Peninsula, which were mostly rural, was not so much the rise of Protestantism, and along with it Calvinism, but religious ignorance and folk religion. The missionaries basically controlled the collective practice of Christianity inside the church and at church-sponsored activities such as philanthropy and education, even though converts may still have exercised personal options while outside the jurisdiction of the church and the missionaries. It is therefore inappropriate to use the standards of Protestantism in judging

${ }^{1}$ Christal Whelan, 'Loss of the Signified among the Kakure Kirishitan', Japanese Religions 19 (1994): 82-103; also, cited in Stephen Turnbull, The Kakure Kirishitan of Japan (Richmond, Surrey, UK: Japan Library, 1998), 10-11; and David S. Blanchard, '.. To the Other Side of the Sky: Catholicism at Kahnawake, 1667-1700', Anthropologica 24 (1982): 77-102.

${ }_{2}$ For a typical Jesuit attitude towards the faith of converts, see Reuben Gold Thwaites et al. (eds.), The Jesuit Relations and Allied Documents (73 vols., Cleveland, OH: Burrows Brothers, 1896-1901), vol. 16, 173; vol. 22, 43-45 [Relations 16: 173; 22: 43-45, henceforth]; and Matsuda Kiichi et al. (eds.), Jûroku shichi seiki Iezusukai Nippon hôkokushû (3rd ser, Kyoto: Dôhô-sha, 1987-2000), vol. 4, 44-45 [henceforth, Hôkokushû 3, 4: 44-45]. 
the authenticity of each personal conversion to Catholicism. What is culturally more significant is to assess how Jesuit Christianity was accepted and comprehended collectively by the population with a non-Christian spiritual background. ${ }^{3}$

The third epistemological issue is how to identify a 'typical' Christian in regions that were once non-Christian. When referring to religious Mohawks, Blanchard mainly means Kateri Tekakwitha, a model female convert, well educated by the nuns at Montreal, rather than numerous unnamed residents in Caughnawaga. Even though Tekakwitha was a convert, Blanchard asserts that her Christian fervour was based on an Iroquois religion based on the 'Sky World', the Iroquoian spiritual world beyond the earth. ${ }^{4} \mathrm{He}$ concludes that the other less Christianised Mohawks must have practised a synchretic system of rituals that were nevertheless compatible with Catholicism.

Along similar lines, in Japan, by dealing with a few late-twentiethcentury successors to local Gotô rituals that can at best be described as a kind of Christianity set within a Japanese framework of Buddhism and Shintô, Whelan retrospectively affirms that their ancestors were never converted to the authentic Christian religion. She does not seem to consider two vital facts. One is that the Goto community on which she focuses was established during the last years of the eighteenth century by the descendants of three thousand immigrants from the Ômura domain, most of whom were descendants of Christian converts. The other is that, due to continual proscriptions, Christianity as established by Jesuits in the islands had been extinct for no less than two centuries when this immigration of Ômura refugees occurred after 1797.

Thus, neither Kateri Tekakwitha nor the ancestors of the Gotô were what can be represented as typical Christian converts. Their religious practices, therefore, should not be considered typically Christian in any way. When discussing Amerindian or Japanese practice, one should give priority to a majority of residents under missionary instruction rather than focusing specifically on the minority of proselytes with special

\footnotetext{
${ }^{3}$ For modern religious individualism, read Alan Neal Galpern, The Religions of the People in Sixteenth-Century Champagne (Cambridge, Mass.: Harvard University Press, 1976). For popular religion in Western Europe, see William A. Christian, Local Religion in Sixteenth-Century Spain (Princeton, N. J.: Princeton University Press, 1981); and A. Lynn Martin, The Jesuit Mind, esp. 226-227.

${ }^{4}$ Blanchard, op. cit., 79-84. For the detailed description of the Iroquois Christian community of Caughnagawa, see Allan Greer, Mohawk Saint: Catherine Tekakwitha and the Jesuits (New York: Oxford University Press, 2005), 89-110.
} 
Christian education or on post-missionary communities that developed without priestly guidance.

More debatable idea can be found in Nicholas P. Cushner's theoretical premise that the non-Christian peoples had their own religions, or belief systems, that are replaceable with Christianity. This simplistic premise has enabled Cushner to conclude that Amerindian 'religions' were replaced by Christianity albeit incompletely. ${ }^{5}$ As the second chapter has indicated, however, what the Jesuits perceived to be an indigenous religion was their own arbitrary combination of various spiritual and unspiritual customs. He therefore needs to prove, in the first place, his basic premise that indigenous Americans had established a set of a belief system fully compatible with Christianity.

Keeping in mind the incorporation of the Christian belief, the authenticity of conversion and the identification of a typical Christian, this case study of Japan will replace existing context-based discussions with perspectives empirically based on Japanese precedents. This analysis will be tripartite. First, the Jesuit descriptions of model converts provide an insight into the criteria used by Europeans to identify Christian converts. Second, incidental observations by missionaries, often more casual than deliberate, hint at the neophytes' unique ethnic understanding of Christianity. Third, the Japanese case presents typical obstacles, in cross-cultural comprehension of the faith, that can be applied to the consideration of the Amerindian experience.

\section{B. Japanese Acceptance and Comprehension of Christianity}

The discussion of the Japanese acceptance and comprehension of Christianity will initially confirm three basic tenets. First, unlike the monotheistic and exclusive tradition of the Christian faith in God, conventional Japanese spirituality was basically polytheistic and harmoniously coexistent, as the second chapter has indicated. Second, owing to the limitations of language and culture, as stated in the third chapter, the priests tailored their approaches to suit the Japanese. Finally, as the third chapter has also described, Jesuit activity comprised, not only preaching but also education, philanthropy and elementary medical care.

${ }^{5}$ Nicholas P. Cushner, Why Have You Come Here? (New York: Oxford University Press, 2006), 3-4, 149-69 \& 197. 
Jesuit rhetoric, however, obscures the extent of the Japanese acceptance of Christianity simply by emphasising the good deeds of model converts. In the missionary accounts, model Christians were faithful followers of Jesuit preaching. These converts respected priests. They attended Mass, prayed regularly and made confessions. They assisted missionaries in persuading others to join the faith. For example, Father Gaspar Vilela praised the converts in Nagasaki in 1571. He gave three reasons. First, their local landowner constructed a church building for the Jesuits. The converts destroyed Buddhist and Shintô constructions in the name of God. They regularly attended Mass and sermons and did penance for their sins. ${ }^{6}$

In the annual report of 1581 also, Father Gaspar Coelho applauded the religious fervour among the converts in Kyoto. According to him, they were willing to follow Christian doctrine and to use Christian icons and rosaries at sacraments. They would gather around Father Alessandro Valignano, travelling distances up to sixty to eighty kilometres, in order to seek spiritual help through the Agnus Dei, sacred icons and rosaries. They also prayed, and in general, they obeyed Jesuit preaching. ${ }^{7}$

However, there is a clear difference of perspective between the priests' appraisals of Christians and their offhand and unintentional references to Japanese responses. For a more accurate understanding of the nonEuropean acceptance of Christianity, one must examine their responses to the missions. To do so, it is necessary to consider the popular image of Jesuit services, including education and philanthropy, based on the order's principles. An ordinary Japanese idea of becoming a Christian was based inevitably on the polytheistic response to this complex missionary service. The converts and future converts developed their own perspectives on the religion of God through their spiritual conventions.

The spiritual climate of Japan, which allowed the Japanese to accommodate and incorporate Jesuit preaching, was basically flexible and absorbent, unless that infrastructure found itself under theological attack. Theologian Neil Fujita compares Christianity and Japanese spirituality to a cone and a doughnut. ${ }^{8}$ Japanese society has always been tolerant

\footnotetext{
${ }^{6}$ Gaspar Vilela to the companions in Portugal, from Cochin, 4th February 1571, in Matsuda, Hôkokushî 3, 4: 44-45.

7 Gaspar Coelho, the annual report of 1581 to the general superior, from Nagasaki, 15 February 1582, in Matsuda, Hôkokush û 3, 6: 38-39.

${ }^{8}$ Neil S. Fujita, "Conic" Christianity and "Donut" Japan', Missiology: An International Review 22 (1994): 43-53.
} 
towards foreign philosophies, including Buddhism, which was introduced gradually in the sixth and later centuries. In a centreless thought structure, numerous spiritualities coexist amicably without being dominated by any one of them in the centre. In Christianity, a single absolute God resides at the centre, or at the summit, and has created and ruled the entire world in His conic structure. When this conic structure was imposed on Japanese thought, Fujita contends, Christianity was rejected. Although this image is plausible from an ideological perspective, it is not fully applicable to the minds of the ordinary people.

Within their centreless spiritual custom based on a receptive tolerance, the ordinary residents accepted Christianity. Father Luis Frois's annual report of 1585 symbolically describes this custom of Japanese society. In that year, as many as thirty-six years after the mission opened in Bungo, the proselytes in the town of Funai installed a large crucifix on the site of a future church building. For the lumber, the congregation chose the Shintô-deity wood that had been annually used for a Gion feast, and carried it on a cart through the town centre. As though they were at a Shintô festival, they presented this wood to the public in a parade that featured dancers accompanied by drums, fifes and other musical instruments. Father Frois commented positively on this parade, which he took as a demonstration of the growing influence of Christianity, since he was not fully aware of the connection between Gion and Shintô. He does not seem to have understood that the converts either treated the lumber simply as another deity or considered this foreign religion to be compatible with Shintô. Above all, in the harmony-based Japanese spiritual system, they could not imagine that God would reject a crucifix made of sacred Shintô wood. ${ }^{9}$

It is through the lens of this harmonious spiritual coexistence peculiar to Japan that any attempts to analyse the degree of acceptance of Christianity should be made. To begin with, for pupils and their parents, the Christian schooling meant another version of Buddhist education. In Bungo of the 1560s, for instance, the missionaries intended to attract the boys of Buddhist temples to their Christian school, where Christian teachers taught not only Christian doctrine but also the same reading and writing as were taught in the Buddhist temples. In 1566 in Kuchinotsu, in the domain of Arima, a former Buddhist temple was

${ }^{9}$ Luis Frois, the annual report on the district of Bungo, from Nagasaki, 20 August 1585, in Murakami Naojirô (ed.), Iezusukai Nippon nenpô [Nenpô, henceforth] (1969), 2: 1-36, esp. 4-5. 
converted into a Jesuit schoolhouse, which successfully recruited pupils from other Buddhist schools. This Buddhist aura of Christian education was enhanced by the fact that ex-Buddhists and ex-students at temples were in charge of teaching on behalf of European priests who had less command of Japanese. ${ }^{10}$

Christian neophytes applied a similar Shintô analogy to Christianity. In the minds of local residents, access to Christian philanthropy and a contribution to it were associated with participation in a traditional system of Shintô mutual aid, or in what was called miyaza or $k \hat{o}$, a commonly-used noun that exists today. The miyaza, a lay Shintô group composed of the upper social echelons in a village or town, worked as a social and philanthropic club as early as the tenth or eleventh century, and continued to function through the Meiji era. While its philanthropic work ended after Meiji, its rôle in organising the feasts of local shrines survives today in western Japan. Throughout pre-modern centuries, this Shintô association played a key part in the feast for distributing harvests throughout local communities. The $k \hat{o}$ originated in a special gathering of the eleventh or twelfth century to listen to Buddhist preaching. It developed throughout the country into numerous small sub-village organisations for mutual aid by the time the first Jesuits arrived in Japan. This type of association usually consisted of the secular participants in a local shrine or temple, often socially influential local residents. It provided social and material assistance to impoverished members by means of charities and feasts. ${ }^{11}$ The priests made use of these existing infrastructures in order to disseminate their own philanthropy, and thus to attract more converts from among the ordinary people. More significantly, whether through the old Shintô or through the new Christianity, the actual participants in the poor relief were the same local Japanese neighbours as before, except for the addition of a small number of stationary foreign or domestic missionaries. For both those helping and those being helped,

${ }_{10}$ Juan Fernández to the companions generally, from Bungo, 8 October 1561; Luis d'Almeida to the companions in India, from Yokoseura, 17 November 1563; Belchoir Figueiredo to the companions in India, 13 September 1566; and Luis Frois, the annual report of 1583 to the general superior, 2 January 1584. Murakami Naojirô (ed.), Iezusukaishi Nippon Tsûshin [Tsûshin, hereafter] (1968-69), 1: 237-38, 350-51 \& 358-59; 2: 54-57; Matuda, Hôkoku-shû 3, 6: 175-76.

${ }^{11}$ For the more details of kô, see Yamaguchi Yaichirô, Shûraku no kôsei to kinô (Tokyo: Hakubun-sha, 1976), 53-55; Takeuchi Toshimi, 'Shakai seikatu', in Nihon minzoku shiryô jiten (Tokyo: Daiichi hôki, 1969); and Hukuda Ajio, Nippon sonraku no minzokuteki kôzô (Tokyo: Kôbun-dô, 1982). 
local philanthropy itself implied some means for Shintô activity, and local people seem to have accepted Christianity as an exotic version of Shintô, and missionaries as Shintô conjurers.

As an extension of philanthropy, the elementary medical care of the mission encouraged belief in the healing power of Christianity. The existing shamanist curative traditions, whether carried on by Buddhist monks or by Shintô and folk remedy prayers, also provided the preconditions for the popular acceptance of the healing deity. Because medical service in those centuries was only for those wealthy citizens who could afford it, the Christian mission represented a generous foreign healing spirituality through philanthropic clinics and leprosaria as well as extensive visitations. Those converts who were in poor health and who lived in areas governed by pro-European lords expected cures from European missionaries. ${ }^{12}$ By using medical care as a way of persuading the sick to accept Christianity, the Jesuits only further blurred the differences between Christianity and Eastern spirituality. ${ }^{13}$

Expecting health and cures from the Christian church was also a transformation of the domestic custom of visiting temples and shrines in those centuries when people believed that an infirm soul or a wicked spirit caused the affliction of a body. There was, for example, a belief called ohyakudo mairi or one-hundred-time visitation. If a person prayed at a healing-related shrine one hundred times, he or she would eventually expel disease from his or her own body. Traditionally Japanese shamans, called miko and yamabushi, played a healing rôle by communicating with the spirit that, they claimed, had produced illness. Missionary documents include passages describing the provision of healing services by temples, as exemplified by the following two references. In 1554, Father Pedro d'Alcáçova referred to an unnamed faithless or careless neophyte, who, having recovered from a fever under the Jesuit instruction for Christianity, fell sick again by visiting a temple for additional cures. According to Brother João Bautista in 1564 , there was a growing idea among people that one must come to church rather than Buddhist temples in order to regain one's health. ${ }^{14}$

12 For numerous references to Jesuit medical care, see Murakami, Tsûshin, 1: 50-55, 178-79, 190-91, 200-01, 256-57; 2: 158; and Murakami, Nenpô, 1: 33 \& 66.

13 See, for example, the Jesuit approach to the lord of Gotô in 1566. Frois, Furoisu Nipponshi (1977-80), 3:15-26; Frois, Historia de Japam (1976-83), part 1, chap. 4.

14 Pedro d'Alcáçova to the companions in Portugal, from Goa, 1554, in Murakami, Tsûshin, 43-60, esp. 55-56; Juan Bautista's letter from Funai, 31 December 1564, 
The curing effect of conversion to Christianity developed into a popular belief in the medicinal value of Christian items of faith such as holy water, at least as far as the Japanese pre-modern imagination could conceive of these religious items. There already was a belief in Japan, prior to the arrival of the Jesuits, that water had the power to restore health, as well as the power to bring about natural disasters. The people in the archipelago had conventionally associated water with a number of miracles, including the restoration of health, youth and beauty. At the entrance to every Shintô shrine, a large water fountain allowed worshipers to clean their hands, mouth and other body parts before stepping into its precincts. In front of a Buddhist altar, a tiny cup of fresh water was offered every morning. In addition, the natural power of water in seas and rivers had both positive and negative associations, including creative and destructive powers, and a belief in the water deity. There are even now shrines dedicated to a water deity, connected to a nearby sea, river, pond or lake, throughout the country, especially where residents repeatedly experienced natural disasters and accidents. The Japanese legend also created the kappa, an imaginary water imp, that was believed to live in a pond or a river and to play tricks on humans, and people blamed it for mysterious water-related accidents. Thus, it was only normal that the Japanese associated spirituality with water.

Based on this traditional spiritual infrastructure, people readily accepted the belief in sacred Christian water. Because the Jesuits used sacred water symbolically for all basic cures, this holy water was popular with the Japanese. In Bungo of the 1550s, remote villagers travelled ten to twelve leagues to ask for water at a Jesuit residence. In Sakai and Kyoto in the 1560s, proselytes took sacred water home in their own containers because they expected a healing effect from it. In Bungo in the 1570 s, villagers gathered at church simply to drink some sacred water. ${ }^{15}$ The annual report on the year 1581 states that this fashion

quoted in Frois, Furoisu Nipponshi, 7: 24-31, esp. 30-31, and in Historia, pt. 1, chap. 53.

${ }^{15}$ Pedro d'Alcáçova to the companions in Portugal, from Goa, 1554; Duarte da Silva to the companions in India, from Bungo, 20 September 1555; Luis Frois, from Sakai, 8 July 1567 (No addressee is recorded.); Luis Frois to Belchior de Figueiredo, from Kyoto, 1st June 1569; and Francisco Cabral to the companions in Portugal, from Kuchinotsu, 9 September 1576. Murakami, Tsûshin, 1: 43-60, 77-92, esp. 55 \& 87-89; 2: 297-320, esp. 315-16; Murakami (ed.), Yasokai Nippon tsûshin (2 vols., 1928, Tokyo: Yûshô-dô, 1975), vol. 1, 444-45. 
even induced non-Christians to visit Jesuits in Bungo. The belief in the healing power of water motivated villagers to seek baptism. ${ }^{16}$

The belief in Jesuit sacred water as a medicine developed into more spiritual acts by the congregation. By imitating the gestures of priests, converts attempted to transform plain water into what they alleged to be an effective medicine. They commonly believed that Christian artefacts without a priest would have the same curative effect. A rosary made of Saint Thomas's crucifix is one example. In the late 1560s, Lord Ômura Sumitada, the renowned Christian patron of the Jesuits, told Fathers Cosme de Torres and João Bautista that he had used this rosary to prepare healing water to succour a non-Christian woman suffering from a chill and fever. In the early 1580s, Father Luis Frois referred to this rosary, now owned by someone else, whom he did not name. According to Father Frois, the owner placed it in a bowl of water and then gave the water to sick people. Father Frois also mentioned another unnamed lay Christian who held beads blessed by the Pope. This Christian steeped them in water and crossed himself, expecting them to have a healing effect. ${ }^{17}$

Other secular examples, of belief in the magical power of Christian objects, included rosaries, communion wafers, and even the soil and wood of sacred places and the dust on Christian icons. In the 1570s, a Christian in Kansai swallowed a shaved piece of rosary bead as a replacement for medication. In Bungo of 1555, when members of a congregation were suffering from destitution and disease, converts used sacred water and communion bread to restore their health. On the martyrs' hill of Nagasaki, where twenty-six Christians were publicly executed on the order of the central Toyotomi administration in 1597, local residents later treated the soil and wood at the site as though they were real medicine. In Funai of the early 1580s, a proselyte attempted to heal the fever of his non-Christian neighbour by having him drink a mixture of

16 Gaspar Coelho, the annual report of 1581 to the general superior, 15 February 1582, in Murakami, Nenpô, 1: 31-116, esp. 65-66; and in Matsuda, Hôkokush $\hat{u}, 3$ rd series, 6:01-80, esp. 34-35.

${ }_{17}$ A letter of 15 August 1569 to the Jesuits in Portugal, by an unknown Portuguese addresser whose name record is not extant; and Luis Frois, the annual report on 1582, from Kuchinotsu, 31 October 1582. Murakami, Tûshin, 2: 175-95, esp. 190-91; Murakami, Nenpô, 1: 165-204, esp. 180-81; and Matsuda, Hôkoku-shû, 3rd series, 3: 383; 6: 81-116, esp. 96-97. 
water and dust removed from a Christian drawing that he kept at his house. ${ }^{18}$

It was the symbolic acts of missionaries that often induced converts to accept Christian items for healing. For instance, Father Francisco de Xavier initially promoted belief in the miraculous power of his disciplinary cane and other items. In 1549, Father Xavier preached to the retainers of Niirô Iseno Kami Yasuhisa, a local lord of Ichiku in Satsuma, today's Kagoshima prefecture. When one of them, a convert called Miguel, asked him for a healing tool, the priest granted him the cane. Father Xavier instructed him to tap sick patients five times while chanting the Hail Mary and the name of Jesus Christ so that they might regain health. Miguel extended this form of symbolism, and in order to cure the sick he used the paper on which Xavier wrote down his prayer. Later in 1562, Brother Luis d'Almeida noted that Miguel preserved this paper in his holy treasure bag and hung it around a patient's neck as a curative. As in the case of Ichiku, Father Xavier gave a passage of the Gospel written on sheets of paper to those who asked him for curative remedies on his trip from Hirado to Kyoto. This case of a testament passage card helps to affirm that Miguel's worship of a prayer card was based on Father Xavier's instruction rather than the proselyte's own interpretation. ${ }^{19}$

It is not clear whether Father Xavier's use of cards was in emulation of the indulgences that were used by the mediaeval European church to remit temporal punishment due for sins that have already been forgiven. In any case, the Japanese custom of honouring or treasuring a Shintô or Buddhist talisman facilitated the acceptance of Christian priests' cards or slips. Father Luis Frois's Historia de Japam refers to an example of the use of the drawing of a crucifix on a sheet of paper as an object of worship. In 1559, a fisherman in Ikitsuki received baptism from Father Gaspar Vilela. This convert, whose name was not recorded, put up the cross drawing in his house to pray for the safe delivery of his baby. Although Father Frois did not connect the incident with Japanese

18 Alessandro (or Alexandre) Vallareggio, in India, to the companions in Portugal, 1572, in Matsuda, Hôkokush û 3, 4: 165-78, esp. 177; Balthasar Gago to the companions in India and Portugal, from Hirado, 23 September 1555, in Murakami, Tsûshin, 1: 93-103, esp. 97-98; Léon Pagès, Histoire de martyrs japonais (1862, trans. by Kimura Tarô as Nippon nijûroku seijin junkyô-ki in 1931), 245; Frois, the annual report on 1584, dating 3 September 1584 at Nagasaki, Matsuda, Hôkokushû 3, 6: 245.

${ }_{19}$ Frois, Furoisu Nipponshi, 3: 15-26; 6: 41-49, 261-74; Historia, pt. 1, chaps. 2, 4 \& 32; Luis d'Almeida to the companions generally, from Yokoseura, 25 October 1562, in Murakami, Tsûshin, 1: 265-91, esp. 271-73. 
customs, it was reminiscent of typical Shintô and Buddhist charms. ${ }^{20}$ In another case, Brother D'Almeida and Father Frois described the converts in Shimabara, of the domain of Arima, who used a charm-like sheet with a crucifix on it instead of the name of a temple or a shrine. They posted a sheet at the main entrance to their homes. Although Jesuit annalists praised this act as a demonstration of strong faith, their own references to the incident suggest the converts' misunderstanding of the significance of the cross as well as their confusion about its connection with Shintô or Buddhist talismans. ${ }^{21}$

There was another Jesuit instruction that made converts believe in the remedial effect of crossing oneself. From the outset of the mission, proselytes seem to have been told to cross themselves in order to regain their health. According to Father Pedro d'Alcáçova, a convert in Kyushu was instructed by an unspecified Jesuit Father to cross himself. Accordingly he recovered from poor health. Subsequently this convert visited a temple for complete recovery and fell ill again. The Father once again advised him to make the sign of the cross. The writer concluded that this repeated crossing finally healed the patient. ${ }^{22}$

This type of popular Christian practice sometimes developed beyond Jesuit control. The worship was directed towards ordinary objects in some cases. There were numerous Christians in Nagasaki who believed in the curative power of the metal nails used on the wooden execution poles for the twenty-six martyrs in 1597. In Funai, despite the ensuing disapproval of Jesuits, the proselytes treasured Father Cosme de Torres's hairs and fragments of his clothing after his death in $1570{ }^{23}$

Archaeological discoveries also suggest the worship of Christian objects as charms among Christians, although it is not known whether missionaries were for or against this form of worship. In the former Jesuit-occupied prefectures like Fukuoka, Nagasaki, Kumamoto, Ôita and Osaka, there are numerous remains that were discovered during the late-twentieth century, including cross-inscribed roof tiles, wooden

${ }^{20}$ Frois, Furoisu Nipponshi, 6: 221-25; Historia, pt. 1, chap. 22.

${ }^{21}$ Luis d'Almeida to the companions in India, from Yokoseura, 17 November 1563, in Murakami, Tsûshin, 1: 336-77, esp. 352-53; \& Frois, Furoisu Nipponshi, 9: 62-81, esp. 64-67; Historia, pt. 1, chap. 45.

22 D'Alcáçova to the companions in Portugal, from Goa, 1554, in Murakami, Tsûshin, 1: 43-60, esp. 55-56.

${ }^{23}$ Pagès, op. cit., 245; Frois, Furoisu Nipponshi, 6: 200-07; Frois, Historia, pt. 1, chap. 19. The attempt to treasure Father Torres's relics was not unique to Japanese converts and had a precedent in the Catholic veneration for relics. 


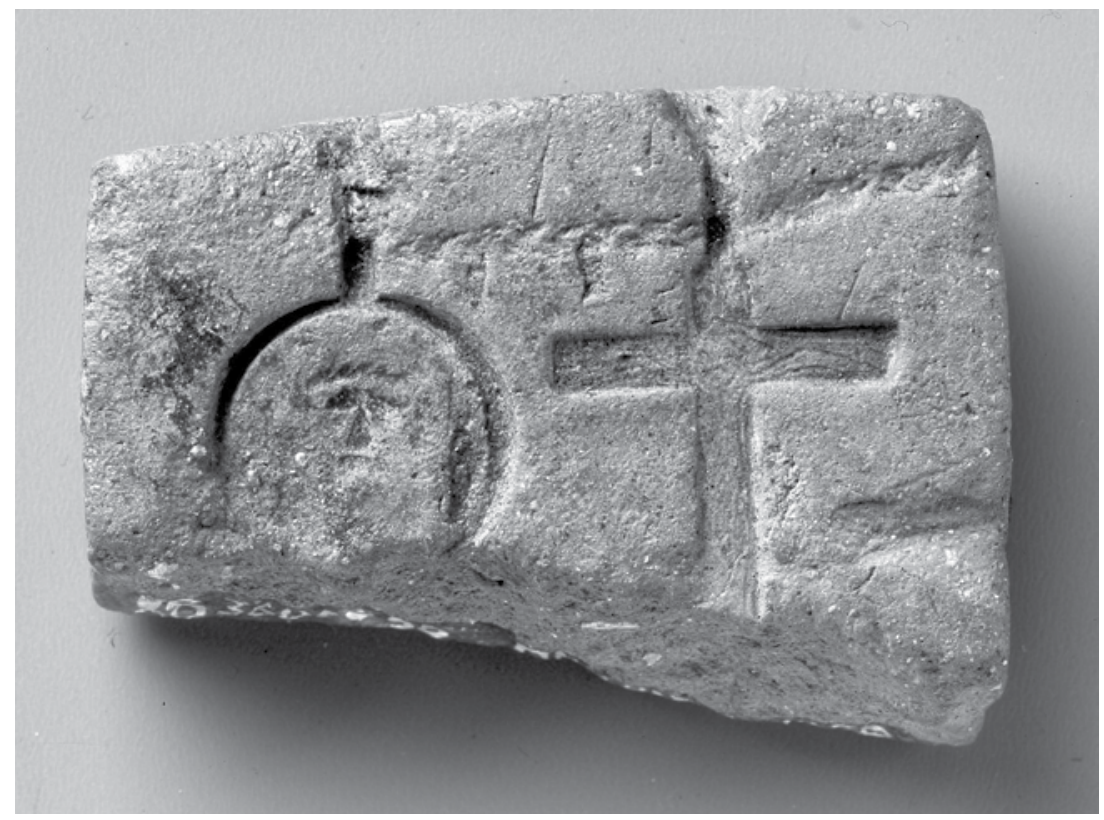

Source: Hakata iseki-gun dai 111-ji shutsudo 'medai jûjika igata', The Fukuoka-city Archaeology Centre

10. Japanese Mould for Medals and Crucifixes in the Late Sixteenth or Early Seventeenth Century: $1.4 \mathrm{~cm} \times 4 \mathrm{~cm} \times 5.5 \mathrm{~cm}, 40$ grams, excavated in Fukuoka in 2002

coffins, ${ }^{24}$ rosaries, medallions, medals, crucifixes and moulds for medals and crucifixes. Of greatest historical interest are crucifixes, medals and their moulds. In the years leading up to 2002, foreign bronze medals and crucifixes, as well as coarse Japanese-made crucifixes, were excavated, but they alone were of little historical value, other than revealing the existence of the Christian church. In March 2002, elaborately manufactured moulds, one for medals and the other for crucifixes, were found in the city of Fukuoka. Yet the moulds alone were insufficient to indicate whether it was priests or converts who were using the cast medals and crucifixes. In December of the same year, however, six Christian medals, made either of lead and tin or of copper alone, were found at Funai in the former domain of Ôtomo. This discovery, together with the previous findings, implied

${ }^{24}$ The Japanese custom of cremation does not leave used coffins behind. 
that converts duplicated and treasured medals for their own purposes, including their use as charms. This also suggests that the locally-made crucifixes were also valued for the same use. The recent archaeological discoveries, combined with the historical documentation, suggest that Japanese Christians believed in the supernatural effects of medals and crucifixes and reproduced them as beneficial charms, in a similar way as other Japanese folk treasured Shintô or Buddhist symbols. ${ }^{25}$

Thus, being a Christian and a member of one of the Japanese congregations during the Jesuit mission involved something beyond existing historical interpretations and beyond the Jesuit rhetoric. It cannot be fully assessed simply by reference to the personal degree of conversion, nor can it merely be denied by reference to the non-Christian remnants in the sacraments and icons to which Whelan makes reference. ${ }^{26}$ When the pervasive destruction of temples and shrines by proJesuit inhabitants under the order of local Christian lords, described in the fourth chapter, is also taken into consideration, it is clear that there were certainly Christian congregations in the archipelago. To understand the Christian identity of Japanese, one needs to examine in detail the sixteenth-century perspectives on self-identification of both Christians and Japanese.

To individual converts in Japan, Jesuit Christianity meant four things. First, Christianity replaced the social ties-especially for mutual help in the case of the Japanese-with which no individual could dispense. Considering, along the same lines, the Christian villages in Hizen that were discussed in the fourth chapter, the Christian religion worked as a social bond that formed a community beyond individual practice. Second, Christianity offered access to worldly benefits by divine grace, as well as to social services, including education and welfare. Third, it was believed that Christianity provided a new healing power that people often thought was analogous to existing spiritualities. Fourth, the new spirituality allowed access to a deity and the benefits associated with him by means of religious objects.

${ }^{25}$ Even though the reproduction of Christian tools may appear to have been associated with the popular religion of mediaeval and early-modern Europe, the Japanese converts were not familiar with it. This Japanese belief in Christian symbols represents the converts' emulation of their popular custom of believing in supernatural powers of Shintô talismans or Buddhist sutras.

${ }^{26}$ Whelan, op. cit., 82-105. 
These aspects of the Japanese version of the faith were results of natural responses to evangelisation rather than the proselytes' reinterpretation of preaching. The missionaries were responsible for borrowing the ready-made systems of education and mutual aid already in existence in Japan. The new system of medical care, even though still rather elementary, was also a generous expansion of the existing healing and shamanistic purifying services available in pre-Jesuit days. The ordinary Japanese folk accepted the Jesuit additions to their spiritual world with no hesitation, and they placed them within the traditional customary frameworks. In other words, they accepted some of the Christian symbolism by placing it within the realm of their native imagination.

The missionary approach, which was revised for use in Japan, was therefore the primary determinant for the acceptance and comprehension of Christianity. The non-Christian cultural infrastructure for the reception of the new religion was of secondary importance. Religious comprehension was determined by Jesuit schemes for converting people, including the Japanese version of preaching, the approaches to central and local daimyô for the collective conversion of their vassals and domain residents, the Society's basic policy of caring for the destitute and the sick and religious education, all of which have been discussed in the previous chapters. The missionaries modified their basic methods according to their understanding of the social and spiritual environment of Japan. Through the limited resources based on this comprehension and on the Jesuits' selective emphasis on specific aspects of missionary services, Japanese Christians developed their own understanding of the religion. Their concept of Christianity was beyond the scope of the rhetorical references to model proselytes in the missionary correspondence. These rules will now be applied to the Amerindian case.

\section{Amerindian Acceptance And Comprehension of Christianity}

In 1642, Father Barthélemy Vimont applauded the neophytes in the Christian réduction of Sillery as model Christians. As proof of their constant faith, he pointed to several examples, such as their eagerness for the frequent reception of the Sacraments, their 'hunger' for God's word, their observance of His commandments, their regular daily attendance at Mass, their voluntary punishment of delinquents, and their zeal for the defence and propagation of the faith. In addition, they prayed to 
God in their dwellings before going out hunting, and thanked Him at the chapel on their return. They observed solemn Christian festivals according to the season. They also refused to participate in a dance or a feast that was thought to be against Christian modesty. ${ }^{27}$ As was the case with Japanese converts, these were the typical observations that the missionaries recorded for presenting their evangelistic achievement in converting the Amerindians to Christianity. ${ }^{28}$

There have been two basic kinds of perspectives about the conversion of native peoples to Christianity in New France. One is that the Jesuits were successful in converting Amerindians to Christian values, an argument stated by James Axtell and Karen Anderson. This perspective is based on an uncritical reading of the Jesuit accounts that are full of the heroic endeavours and missionary achievements of the priests among indigenous converts. By contrast, the second perspective is that the missionaries were unsuccessful in converting the Amerindians. In other words, the conquest and subordination existed only in the rhetorical universe of The Jesuit Relations, and not in the actual communications between missionaries and native peoples, a claim recently postulated by Carole Blackburn. According to this thesis, Amerindian converts subverted the missionaries' intended meaning and the significance of the Christian preaching by using their own cultural logic. ${ }^{29}$

However, neither of these opposing standpoints, premised as they are on the degree of success, draws a true picture of the Amerindian acceptance and comprehension of Christianity. As the missionary case in Japan shows, Christian conversion was a result of the cross-cultural communication between European evangelists and future non-European converts. For an authentic portrait of conversion, one may well consider both the evangelists' adaptive approach and the Amerindians' cultural compatibility to it, under the four categories revealed in the analysis

27 Vimont's Relation of 1642, in Relations 22: 43-45.

28 Two more examples among many include Paul Ragueneau's letter to Mutius Vitelleschi, general superior, at Rome, from Trois-Rivières, 28 July 1641; Jean de Brébeuf's letter to Vitelleschi at Rome, from Québec, 20 August 1641; in Lucien Campeau (ed.), Monumenta Novae Franciae (9 vols., Roma: Instittum Historicum Societatis Iesu; \& Montréal: Bellarmin; or Québec: Les Presses de l'Université Laval, 1967-2003), vol. 5, 20-24 \& 26-29 [Campeau, Monumenta, 5: 20-24 \& 26-29, henceforth], esp. $22 \& 27$.

${ }^{29}$ James Axtell, The Invasion Within (New York: Oxford University Press, 1985), 91-127, 277-80; Karen Anderson, Chain Her by One Foot (New York \& London: Routledge, 1991), 224-29; and Carole Blackburn, Harvest of Souls (Montreal \& Kingston: McGill-Queen's University Press, 2000), 105-139. 
of Japanese converts. These categories include, first, social ties; second, access to social service and to worldly benefits by divine grace; third, curative methods; and fourth, religious talismans.

\section{Christianity as Social Ties}

Just as Christianity took over the Japanese social ties in association with Shintô and Buddhism, it also played a similar rôle in New France. In the Amerindian imagination, baptism was affected by a desire for reunion with deceased relatives in the next world, after death. The native peoples-Innu, Algonquin and Huron-had a traditional belief that one would go to the land of the dead somewhere distant to the west. The Jesuits borrowed this basic idea of spiritual migration after death in preaching about heaven, where God resided, and where native people went after death, if baptised just before death. In 1636, a Huron woman refused baptism when she learnt that her dead nonChristian relatives, who had not been baptised, had therefore not gone to heaven. The same understanding could also work in the opposite way, as evidenced in that same year. Huron parents whose children were baptised at death sought their own baptism from the missionaries, since they did not wish to be separated from their children, who they assumed had gone to heaven. As well, according to Father Vimont in 1642 , a healthy native resident in Sillery explained to a missionary that he wanted to be baptised in order to reach the same destination as his dead wife, who had died as a Christian and, he believed, had gone to heaven. ${ }^{30}$

There were two factors that underpinned these ideas. One was that of the Jesuit preaching about heaven. The priests frequently explained to the indigenous people that Christians could go to heaven in the sky after death. According to the missionary preaching about heaven given to converts in Sillery in 1646-47, the sky was used as a synonym

${ }^{30}$ Paul le Jeune's Relations of 1634 and 1637, in Relations 6: 177-79; 11: 101-03; Paul Ragueneau's Relation of 1651-1652, in Relations 38: 23-25; Jean de Brébeuf's Relation of the Hurons of 1636, in Relations 10: 31-33 \& 143-47; François Joseph Le Mercier's Relation of the Hurons of 1637, in Relations 13: 251; \& 14: 109; and Barthélemy Vimont's Relation of 1642, in Relations 22: 109-113. For the Innu and Algonquin land of the dead, see also Alfred Goldsworthy Bailey, The Conflict of European and Eastern Algonkian Cultures, 1504-1700 (1937, 2nd ed., Toronto: University of Toronto Press, 1969), 138-39. For the Huron or general Iroquoian idea of the land of the dead, see also Elizabeth Tooker, The Ethnography of the Huron Indians, 1615-1649 (1964, Syracuse: Syracuse University Press, 1991), 140 \& note 65. 
for heaven. The sky was explained as the beautiful and ravishing place of eternal dwelling that could console Christians. The other factors shaping native views of baptism were the numerous baptisms of those about to die. Throughout the years of the mission in Huronia, the evangelists were normally unsuccessful in persuading healthy Hurons to accept baptism. Instead, they attempted to baptise native people on their deathbeds so that they might die as Christians. This was also often the case with the mission to the Innu and the Algonquin around the French outposts. These two factors together meant to the bereaved that their deceased family and kinship members had gone to the Christian heaven rather than to the traditional land of the dead. ${ }^{31}$

In the réductions near the French settlements, Christianity introduced other social bonds that had been unknown in the Huron mission near distant Lake Simcoe. The interests of both the native residents and the evangelists coincided. When Amerindian parties first moved to Sillery or Trois-Rivières in 1637, they took advantage of material and human resources under Jesuit control, which were incentives to accepting Christianity, in order to re-establish their own communities. The missionaries attempted to control the native réductions by using Christianity as a new social norm that would unite all the native residents as a community. ${ }^{32}$

Yet Christianity was slow to transform itself into a form of social bond in the Amerindian settlements. Even in Sillery, which was more religious than any other contemporary Laurentian réduction, the native residents resisted for nine years before most of the people accepted Christianity and got socially united as a native Christian community. The Jesuits only succeeded in completely converting the residents of Sillery as late as $1646 .^{33}$

There were two reasons for this delay. First of all, births and deaths, along with constant migration, made the task of the missionaries difficult. The location of this Algonquin and Innu settlement was convenient for both those who intended to stay near Quebec temporarily and those who wanted to join the native community permanently. In the Relation of $1642-1643$, for example, Sillery was reported to have

${ }^{31}$ For the preaching about heaven, see Le Jeune's Relation of 1637, in Relations 11: 101-103; Le Mercier's Relation of the Hurons of 1637, in Relations 13: 29-31 \& 39-41; Jérôme Lalemant's Relation of the Hurons of 1643-44, in Relations 26: 179-81, 193-95 \& 203-205; and J. Lalemant's Relation of 1647, in Relations 31: 149-51.

${ }^{32}$ Le Jeune's Relations of 1637 and 1638, in Relations 12: 161-65; \& 14: 205-17.

33 J. Lalemant's Relation of 1645-1646, in Relations 29: 65-67. 
accommodated Huron traders, as well as the Attikamègue, over winter. The Huron parties repeatedly wintered in Sillery during the 1640s. The settlement also continued to accept more Algonquin, Innu and other people who intended to reside there. ${ }^{34}$

The other reason for the delay was that native people had to cope with the Jesuit resistance to mass baptism. Instead, the priests only baptised those individuals who showed sufficient piety and constancy of faith. Because of this individual-based baptism, it was impossible for all the residents to be baptised within a short period. Being a Christian was also not a prerequisite for entering a settlement. In order to remain in the settlement, however, native residents had to become model Christians. In other words, they could not simply request one rite or another from time to time. In the Relation of 1642, Father Jérôme Lalemant never failed to mention the religious requirement given to Sillery residents. Perhaps based on this unwritten Jesuit strategy, the colonial French authorities announced to the Sillery headmen in the same year that non-Christians were not allowed to remain in the settlement. In 1645, Father Lalemant was finally able to claim that all the native Sillery residents were either Christians or catechumens. A year later, in the Relation of 1646, he noted that almost all the indigenous residents there had been baptised. ${ }^{35}$

\section{Christianity as a Key to Service and Worldly Benefits}

For Amerindian converts, accepting Christianity meant access to human and material resources through the missionaries, especially if they resided near the French settlements. Like their Iberian predecessors in Japan, the French missionaries and sympathetic officials provided indigenous people with all kinds of social services and other related benefits. For instance, the Jesuits provided native children and, later, adults with food and clothing at seminaries. The Ursuline Nuns did the same for Amerindian girls. Also, as mentioned above, accepting Christianity provided the decreasing native Laurentian population with an opportunity to get French help to re-establish a community in

\footnotetext{
${ }^{34}$ Vimont's Relation of 1642-1643, in Relations 24: 67-69 \& 103-105; J. Lalemant's Journal des PP. Jésuites of 1645, in Relations 27: 91; J. Lalemant's Journal des PP. Jésuites of 1647, in Relations 30: 155; and J. Lalemant's Journal des PP. Jésuites of 1649, in Relations 34: 63.

${ }_{35}$ J. Lalemant's Journal des PP. Jésuites of 1645, in Relations 27: 121; and J. Lalemant's Relations of 1646 and 1648, in Relations 29: 65; \& 33: 49-51.
} 
the réductions. The Jesuit missionaries and Hospital nuns made efforts to save the destitute or ill among the Amerindians. Moreover, in the fur trade, native Christians were better treated than non-Christians receiving better prices for furs, additional presents, and places of honour at councils held at the French settlements. ${ }^{36}$

There were several examples that support this linkage of social services with Christianity. Following the first réduction of Sillery, the collaborative French-Amerindian réduction programme expanded to other areas, such as Trois-Rivières, Tadoussac and île d'Orléans. The hospital in Quebec was always crowded with native patients. Also, young Huron men who wintered near the French settlements in the early 1640s received both material help and baptismal instruction from the missionaries. According to Father Vimont in 1643, catechism instruction to Algonquin children in Sillery was accompanied by such rewards as knives, bread, chaplets, caps and axes. ${ }^{37}$

There was almost always a strong connection between the fur trade and Christianity in the minds of native people. In the village of Ihonatiria, able-bodied Huron traders requested baptism. This village was the only place at which the Jesuits were able to establish a small missionary centre after reopening the Huron mission in the mid1630s. Co-incidentally it was one of the villages that had established a trading relationship with the French in Quebec. Also, in the 1630s, when the Hurons who asked for baptism were mostly the ill or dying, a small number of healthy men, who had made trade journeys to Quebec, sought baptism or helped with missionary work. They expected preferential treatment in trade as Christians. ${ }^{38}$

\footnotetext{
${ }^{36}$ For the preferential treatment of indigenous converts, see Paul le Jeune's Relations of 1636, 1637 and 1639, in Relations 9: 287-89; 16: 33; 12: 243-47 \& 257-59; also cited in Bruce G. Trigger, the Children of Aataentsic (Kingston \& Montreal: McGillQueen's University Press, 1976), 547. It was not difficult for the French settlers in Quebec to identify native Christians because the men of the villages that accepted missionaries normally carried a priest's letter to the missionary station in Quebec. See the letter of Barthélemi Vimont, superior, to Mutius Vitelleschi, general superior, at Rome, from Quebec, 28 September 1643, in Campeau, Monumenta, 5: 631-34, esp. 631; Charles Garnier to Henry de Saint-Joseph, at Paris, from [the Huron village of] Saint-Joseph, 14 May 1646, in ibid., 6:.471-76, esp. 473; Garnier to Saint-Joseph, at Paris, from Saint-Marie, 25 April 1648, in ibid., 7:242-46, esp. 243.

${ }^{37}$ Vimont's Relation of 1642-43, in Relations 23: 309-13.

${ }^{38}$ For the positive effect of trade on the mission, see Jean de Brébeufs Relation of the Hurons of 1635, in Relations 8: 101-103, 149-51; and Le Jeune's Relations of 1637 and 1638, in Relations 11: 135; \& 14: 77-83. See also Trigger, op. cit., 546-550.
} 
The Amerindian expectation to the missionary version of Christianity, however, went beyond access to social services. The native people lived in a world where shamanism ruled every aspect of life. They did not consider that Christianity and church would remain strictly within a European concept of religious and philanthropical rôles. Through Christianity they expected such worldly shamanistic benefits as they would seek traditionally from indigenous shamanism, including animism, such as locating game animals and curing disease. ${ }^{39}$

In the religious practice of neophytes and potential converts, the Christian God brought the additional power to control weather to protect food crops, for example. In 1628, the Hurons in the village of Ihonatiria prayed with Father Jean de Brébeuf in front of a crucifix for rainfall and a plentiful harvest. In June 1635 again, the people of Ihonatiria sought help from the Jesuits after they found a native shaman, the so-called 'arendiowane' or 'arendiwane', unsuccessful in bringing rain. Under the priests' instruction, they made daily processions and a novena, or a cycle of nine prayers, and finally they enjoyed abundant rainfall. Their participation in the same religious prayers brought rain again in late July, and consequently a good harvest. In the dry summer of 1638 also, the Huron villagers of Ossossané depended on Christian Masses for securing rainwater from the sky. ${ }^{40}$

Both the Hurons and the Jesuits were responsible for establishing the image of God as the weather controller. The Huron people had a shamanic custom of throwing tobacco into a fire in honour of the sky for a good harvest and other benefits. The native people also had a custom of asking their shamans to bring rainfall by means of dreaming, feasting and dancing. The shamans claimed that they could cause and stop the rain and winds. Both in 1628 and in 1635 the Huron people asked the priests for help only after the failure of their shamans. The missionaries took advantage of this opportunity to persuade the Hurons that praying only to God could bring rain and a harvest. The priests acted as substitutes for the rain-bringing shamans. Simultaneously Christian prayers replaced traditional Huron activities to control the weather. ${ }^{41}$

\footnotetext{
${ }^{39}$ For the example of animism, see Brébeuf's Relation of the Hurons of 1636, in Relations 10: 159-69.

${ }^{40}$ Brébeuf s Relation of the Hurons of 1636, in Relations 10: 35-49; and J. Lalemant's Relation of the Hurons of 1639, in Relations 17: 135-37.

${ }^{41}$ Brébeuf's Relations of the Hurons of 1635 and 1636, in Relations 8: 123-25; \& 10: 193-95; J. Lalemant's Relation of the Hurons of 1642, in Relations 23: 55; and Paul Ragueneau's Relation of the Hurons of 1647-48, in Relations 33: 221.
} 


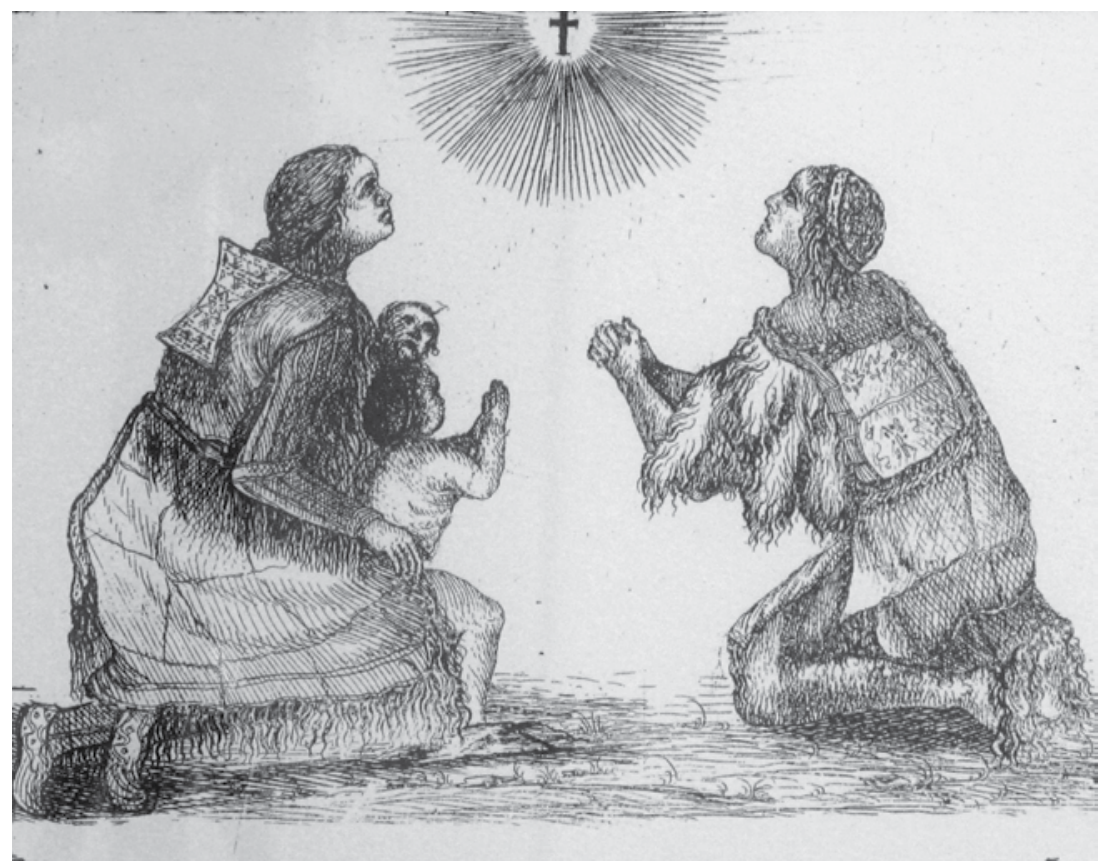

Source: Carte de la Nouvelle France, in Francesco Giuseppe Bressani, SJ, Novae Franciae accurata delineatio, 1657; (C) Dép. Cartes et plans/Bibliothèque nationale de France

11. Seventeenth-Century Image of Native Women and Children Praying to God

A similar association of prayer with material rewards was applied to hunting and fishing. The Amerindians expected to use divine Christian power to summon wildlife. In 1638, Father François Joseph le Mercier referred to a Huron headman, an influential pro-Jesuit supporter in Ossossané, who was described as having spoken honourably of God and His law, and to have attributed the success of his fishing to Christian prayers. ${ }^{42}$

The Innu and Algonquin peoples, too, considered the Christian God to be capable of contributing to successful hunting. Father Le Jeune made repeated references to their belief. In the Relation of 1639, he referred to an old Innu man. The man told his son-in-law to ask God for a moose when he went out hunting. Father Le Jeune also wrote

${ }^{42}$ Le Mercier's Relation of 1638, in Relations 15: 125. 
about a band of Innu hunters who wintered away from Sillery in 1638-39. When they returned to the réduction, they told the missionaries that they had maintained a constant supply of their game by thanking God for every catch. In the two Relations of 1639 and of 1640, native Christians in Sillery made it a rule to fall on their knees and thank God for the game they had just caught and killed. Father Vimont wrote about a neophyte in the same settlement. Before every hunt for wild game, this convert prayed to God for success with the aid of a crucifix..$^{43}$

It was the missionaries who encouraged their neophytes and potential converts to pray to God for successful hunting. To borrow Father Paul Ragueneau's expression, presumably conveyed to the native Christians, God was the sovereign Lord of animals as well as of men. In December 1633, Father Le Jeune proposed that his hungry Innu host should offer prayers to God, who had 'made heaven and earth', before departing for hunting. According to him, these native people consequently caught beavers, porcupines and moose, while the 'apostates'- probably those who resorted to traditional hunting rituals-returned without game. The Relation of 1647-1648 notes that the Jesuits attempted to replace manitou with the Christian God as the spirit that would bring success in hunting. For example, among the Abenakis, to whom the Jesuits expanded their mission with the help of Innu converts, Christians and non-Christians coexisted. When Father Gabriel Druillèttes accompanied his Abenaki converts in their winter hunting of 1647-48, only his Christian party that believed in God for the successful chase was reported to have enjoyed sufficient game. ${ }^{44}$

By becoming Christians, the Amerindians also expected help in warfare from the Jesuits. In 1637, Father Le Jeune referred to indigenous men, apparently Innu, who were being instructed about abandoning some non-Christian customs before being qualified to become Christians. They sought the priests' prediction of a future war and God's assistance in it. Accordingly they learnt from the missionaries prayers for their safe return from battle. In the Huron country also, the people expected that the missionaries would intervene with God in order to

\footnotetext{
${ }^{43}$ Le Jeune's Relations of 1639 and 1640, in Relations 16: 49-51; 18: 149 \& 157; and Vimont's Relation of 1642, in Relations 22: 57-59.

${ }^{44}$ Le Jeune's Relation of 1634, in Relations 7: 145-59; Lalemant's Relation of 16471648, in Relations 32: 273; and Ragueneau's Relation of 1651-52, in Relations 37: 195.
} 
predict for them where their enemies were and in what force they would come. ${ }^{45}$

There was an Amerindian belief in manitou and an oki as personal guardians in warfare. During one of his first meetings with Innu bands, Father Le Jeune learnt that they believed that manitou was present in battles. The manitou, he stated, would protect those whom it favoured, and would kill their enemies. Even though Father Brébeuf did not use the word $o k i$, he reported on a similar belief among the Hurons, who believed in a kind of war divinity that they imagined to be a little dwarf. On departure for a battle, the dwarf would caress those who would enjoy a victorious return, but would strike on the forehead those who would lose their lives. Also the sun, or Agreskoui, was war divinity among the Huron and Iroquois peoples. In 1648, Father Ragueneau identified the sun as the Huron people's war divinity. Later in 1653, Father Francis-Joseph Bressani referred to it as Agreskoui. Also, Huron shamans, or arendiwane, claimed that they were capable of various war-related predictions, such as whether a war would be successful, whether the enemy was approaching a village, how many were coming, and where they waited in ambush. This type of shaman resorted to an oki that he claimed would enter his body or appear to him in a dream or a vision. ${ }^{46}$

Furthermore, the priests inadvertently helped the Amerindians to associate God with manitou or a great oki. It was Father Le Jeune who first identified manitou as the devil who worked against God, or so he implied to a group of the native people. Father Le Jeune's words enabled the Innu people to imagine that the European God was equivalent to their manitou. According to his Relation of 1634, he himself took the initiative for explaining even to an Innu group that manitou was the devil, which would hinder God. He wrote that he had said to those who felt frightened of manitou, 'Do not fear, the devil will not harm you as long as I am with you, for he fears those who believe in God; if you will believe in God, the devil will flee from you'. According to Father Le Jeune in the Relation of 1636, an Innu shaman called God

\footnotetext{
${ }^{45}$ Le Jeune's Relation of 1637, in Relations 11: 217; and J. Lalemant's Relation of 1639, in Relations 17: 119-21.

${ }^{46}$ Le Jeune's Relation of 1634, in Relations 6: 175; Brébeuf s Relation of the Hurons of 1636, in Relations 10: 183 \& 197; J. Lalemant's Relation of the Hurons of 1640, in Relations 19: 83; and Ragueneau's Relation of 1647-48, in Relations 33: 193 \& 221-25; and Francis-Joseph Bressani's Relation of 1653, in Relations 39: 13 \& 207-209.
} 
'your manitou' in front of Father Jacques Buteux. Soon the Innu learnt to regard God as the good manitou and the devil as the bad manitou. ${ }^{47}$

The Hurons also understood God as a version of ondaki or an oki. ${ }^{48}$ In 1642, Father Lalemant recounted a story about a non-Christian Huron man who fasted for a vision of an oki. In this indigenous imagination, an oki resided in the sky and showed up on the ground by descending from the sky, then ascending afterwards. In the Relation of 1636, Father Brébeuf stated that he explained about God by metaphorically using this Huron idea of an oki in the sky, which ruled the weather and climate. ${ }^{49}$

For non-Christian Amerindians to understand any spirituality, their only possible framework for comprehension would come from their indigenous shamanism based on spiritual powers like manitou or an oki. Beyond its religious realm, Christianity also represented a means to predict astronomical phenomena, or changing weather and climate patterns. This did not, however, persuade the native people to become Christian in a Jesuit sense. Quite the opposite: the priests' use of their astronomical knowledge only strengthened the identification of themselves as powerful and formidable shamans. This identification even enhanced the interconnection between traditional shamanism and Christianity in the mind of the indigenous people. In the Relation of 1639, Father Lalemant recounted his and his brethren's experience after they predicted the eclipse of the moon and sun, which the Huron people feared. The indigenous people began to imagine that the priests could recognise and determine all future events, including the upcoming harvest and war strategies of enemies. At the same time, the Amerindians were critical of the priests for not warning them of outbreaks of epidemic diseases and for not offering preventive or curative remedies to them as shamans would profess to do. ${ }^{50}$

The Jesuits were even compelled to adapt themselves to indigenous shamanistic activities. Three examples are pertinent. One was the use

${ }^{47}$ Le Jeune's Relation of 1634, in Relations 6: 175; 7: 85-87 \& 181-83; Le Jeune's Relation of 1636, in Relations 9:75-77; and Le Jeune's Relation of 1637, in Relations 12:7-9.

${ }_{48}$ There were several $o k i$, or ondaki to be more precise, not just one in the Huron minds.

${ }_{49}$ Brébeuf's Relation of the Hurons of 1636, in Relations 10: 161; and J. Lalemant's Relation of 1642, in Relations 23, 155-57.

${ }_{50}$ J. Lalemant's Relation of 1639, in Relations 17: 119-21; and also partially quoted in Axtell, op. cit., 102. 
of feasts, typical native rituals. In 1637, Father Buteux held a feast to which he invited Innu and Attikamègue peoples in Trois-Rivières to persuade them to pray for God. The other examples involved dreams, on which Amerindians relied for making decisions in every aspect of their lives. In January 1634, Father Le Jeune feared being deserted by his Innu hosts, who tried to conserve their food by abandoning him. To save himself, the Father claimed that he had dreamed just the opposite, that the Innu would capture two moose. Again in 1637, to convert an Algonquin group whose dreams prevented them from accepting the faith, Father Le Jeune warned them, 'We will dream that you all will be converted'. These cases imply that the native people had opportunities to believe that the Christian priests held a feast as they did, and that they made predictions and decisions as in shamanism. ${ }^{51}$

\section{Christianity for Healing Power}

The curative method that the Jesuits applied to the ill caused the latter to associate Christianity with healing power. This belief was stronger among the Amerindians than among the Japanese, who had immunity to European diseases and suffered little from them. The Jesuit accounts contain numerous accounts of anonymous Amerindians who sought baptism when they wished to survive a sickness or regain their health. In their minds, becoming a Christian, or even being baptised by European priests, would bring succour from fatal diseases. Simultaneously most converts kept their traditional curing rituals which, at least in their minds, did not conflict with Christianity.

Because the relationship between missionary healers and ill indigenous people varied slightly according to region, there were two basic versions of this acceptance of the curative God. In the first adaptation model, healing power was interpreted positively, as seen especially among the peoples near the French settlements, who met French settlers beside the Jesuits. This idea was conspicuous among nomadic peoples, such as the Innu, Algonquin and Attikamègue, as well as the later Huron refugees to Quebec, all of whom eventually lived near the French settlements in the Saint Lawrence Valley. In the second model, the priests' power was interpreted negatively, as killing power. This perspective was common especially among remote peoples, such

${ }^{51}$ Le Jeune's Relation of 1634, in Relations 7: 169; and Le Jeune's Relation of 1637, in Relations 11: 203; \& 12: 171. See also Axtell, op. cit., 111-12. 
as the semi-sedentary Hurons by distant Lake Simcoe, who met few Europeans except for the missionaries, whom they took to be typical Europeans.

\section{a. Positive Interpretations}

The nomadic peoples around the French settlements asked priests to baptise them when they were ill or dying. Baptism was often requested as an addition to traditional healing. In the Relation of 1633, a grandmother of a sick Algonquin child said that she would be satisfied to have Father Brébeuf baptise the child, given that the Father could cure him. The child's parents and grandmother tried baptism as another option for healing, in addition to a native healing ritual, which included howling, playing a tambourine-like instrument, blowing on the head of the child and whistling. In the winter of 1647-48, Attikamègue Christian parents of an ailing child turned to God only after the failure of a native shaman's healing rituals. According to Father Ragueneau, this neophyte soon recovered his health. This last incident also implies that the curative use of baptism and shamanistic healing coexisted even among converts. ${ }^{52}$

Requests for baptism were mainly for curing illness. In 1634, Manitouchatche, an Innu on good terms with the missionaries, begged for baptism to recover from his illness. In 1636, Father Le Jeune noted that the Innu people tried to summon the missionaries in order to save their stricken children by baptism. The same case was reported among the Algonquin in 1637. In 1647, after falling extremely ill, an Abenaki shaman sent for Father Gabriel Druillettes to heal him through baptism, and he regained his health. ${ }^{53}$

The indigenous people also believed in the missionaries' healing power in their other sacraments and prayers. In 1637-38, an Innu group who had settled in Trois-Rivières found their people afflicted with illness. In an attempt to avoid the spread of disease, they decided at a council to have recourse to God, to pray to Him regularly and to seek religious instruction from the priests. In 1643-44, a native woman in Sillery, who may have been a Christian or else in the process

${ }^{52}$ Le Jeune's Relation of 1633, in Relations 5: 233; and J. Lalemant's Relation of 1647-48, in Relations 32: 297-99.

${ }^{53}$ Le Jeune's Relation of 1634, 1636 and 1637, in Relations 6: 117-27; 8: 247; \& 11: 131-33; and J. Lalemant's Relation of 1647, in Relations 31: 197-99. 
of receiving instruction for baptism, had an extremely sore throat. She asked a missionary to cure her. In the Relation of 1645-46, a sick Algonquin man approached the Jesuits in Huronia. The priests helped him to pray to God for his cure. According to Father Ragueneau, this neophyte soon recovered his health. In the same report, on two occasions, another Algonquin neophyte declined conventional curative rituals and instead sought the help of the missionaries to pray to God for curing his sick child. Father Ragueneau proudly stated that the child recovered his health in both cases. Yet his deliberate reference to this model Christian also suggests that many other less pious neophytes tended to rely on both Amerindian healing rituals and Christiansacraments. ${ }^{54}$

In the second quarter of the seventeenth century, this belief in the Christian God's ability to heal was accepted by Amerindians in areas remote from the French outposts, and by the Huron people. To a large degree, Christianity functioned among the Huron people in the same positive way as among the nomadic peoples such as the Innu and Algonquin. The Hurons asked priests to baptise them when they were ill or dying. They also believed in the healing power of the missionaries' other sacraments and prayers. Baptism was requested as a substitute for native healing rituals. ${ }^{55}$

In a similar manner, the indigenous peoples expected that a safe pregnancy and birth could be ensured by the Jesuits. According to Father Lalemant, in the Relation of 1647, a Christian woman in danger of death from child bearing had recourse to the missionaries who visited the Island of Miskou, in the Gulf of Saint Lawrence. The lives of both the woman and her baby, baptised immediately at birth, were saved. In the Relation of 1647 also, a native catechumen and her unborn baby in Sillery were reported to have been saved by prayers to God when they were almost dying. ${ }^{56}$ Because the Jesuits could not really guarantee benefits through their prayers and actions, they received blame as well as gratitude for the results of events beyond their control.

${ }^{54}$ Le Jeune's Relation of 1638, in Relations 14: 263-65; Vimont's Relation of 164344, in Relations 26: 79-81; and Ragueneau's Relation of the Hurons of 1645-46, in Relations 30: 115-17.

${ }_{55}$ Brébeuf's Relation of the Hurons of 1636, in Relations 10: 13; Le Mercier's Relation of the Hurons of 1637, in Relations 13: 85-87; and Joseph-Marie Chaumonot's letter to the General Superior Mutio Vitelleschi, at Rome, from the country of the Hurons, 24 May 1640, in Relations 18: 23-27.

${ }^{56}$ J. Lalemant's Relations of 1647 and 1647-48, in Relations 32: 51-53; 277-79. 


\section{b. Negative Interpretations}

Other people believed baptism of the dying, along with other sacraments, as the acts of the Jesuits, to cause immediate death. This conviction was based on the tendency of priests to baptise the dying without reservation. In the Relation of 1636, Father Le Jeune referred to an Innu or Algonquin woman who asked the missionaries not to baptise her sick husband, for she did not want to lose him immediately. In the early 1640s, native non-Christian residents in Sillery firmly believed that baptism and prayer together would cause them to die. In 1647, a non-Christian patient in the hospital of Quebec rejected the sacrament of life that he imagined would cause his death. ${ }^{57}$

This negative interpretation grew even stronger among the Huron people. In understanding the power to influence lives and health, the Hurons received more negative impressions than positive ones. They suspected that killing power, rather than healing power, existed in anything related to the missionaries, such as pictures of Jesus or the Virgin Mary, European kettles, European clocks, the priests' books and their tabernacles. One individual who maintained a traditional animistic belief asked the priests whether they were creating the malady in the missionaries' house to spread disease. Some imagined that the Jesuits were practising their sorcery by keeping their house entrance closed when the priests were merely engaged in morning meditation. ${ }^{58}$

There were outbreaks of epidemics that altered the native perception of the evangelists who propagated the belief in God. The resumption of the Huron mission in the mid-1630s coincided with repeated outbreaks of European-derived epidemics, to which the Amerindians were susceptible. Because baptism was mainly given to the diseased or dying, not many survived baptism. Referring to both baptism and disease within a single paragraph, Father Jérôme Lalemant wrote implicitly to Superior General Mutius Vitelleschi that one thousand baptisms accomplished by the priests among the Hurons in 1640 were closely connected with the fatal damages by contagious diseases. In 1653, Father Francis-Joseph Bressani admitted retrospectively that, of the twelve thousand Huron people whom the Jesuits claimed to have baptised in the mid-1630s, most of them did not survive diseases. Faced

57 Le Jeune's Relation of 1636, in Relations 9: 61; Vimont's Relation of 1642-43, in Relations 24: 25-27; and J. Lalemant's Relation of 1647, in Relations 31: 159.

${ }^{58}$ Le Mercier's Relation of 1637 and 1638, in Relations 14: 103-105; \& 15: 17-35; J. Lalemant's Relation of 1640, in Relations 20: 31-33 \& 37. 
with the numerous deaths by illness, the Huron people instinctively believed the causes to rest in the Christian mission. ${ }^{59}$

Even though the Hurons were not the only Amerindian groups to suffer epidemics, there were four basic reasons for them to reach such a conclusion. First, the missionaries stayed all year round in the Huron country rather than making seasonal visits from Quebec, as they did to nomadic bands. Even the residents in the réductions closer to Quebec had the option of leaving behind the Europeans when the native people went off to winter hunting. ${ }^{60}$ Second, for the Hurons, the priests and their assistants were the only Europeans the indigenous villagers saw because of the distance from the French settlers in Quebec or TroisRivières. Thus, they thought that all the Europeans were shaman-like priests. Third, except for traders and seminarians, the Huron people had little opportunity to enjoy such medical and material assistance as might be expected at the French outposts and the native réductions. Fourth, the Hurons were unable to understand the evangelists' intention of travelling such long distances to live amongst them. Even more puzzling was the fact that the missionaries, unlike native shamans, claimed no material profit or advantage for themselves. ${ }^{61}$ In these circumstances, the Hurons were prone to associate mortal epidemics and subsequent deaths with the missionaries.

\section{c. Factors behind the Belief in Healing Power}

To understand the Amerindian view of Christianity as a cause for healing and, at the same time, for killing, one should consider the indigenous beliefs about disease. Although the Jesuits left behind no detailed observation of Innu or Algonquin ideas of disease, Father Le Jeune, at least, recognised the Innu belief that the manitou would cause death and illness. According to Father Ragueneau, the Hurons recognised three kinds of disease. The first kind was common and curable with natural remedies. The second kind was caused by the materialistic

59 J. Lalemant to Mutius Vitelleschi, general superior, at Rome, from the country of the Hurons, 1 April 1640, in Campeau, Monumenta, 4: 467-70, esp. 468-69; and Francis-Joseph Bressani's Relation of 1653, in Relations 39: 145. See also Father Le Mercier's deliberate reference in 1637 to the first adult Huron baptised in health as well as to the recovery of those baptised in sickbed, in Relations 14: 77-79 \& 109.

${ }^{60}$ Vimont's Relation of 1643-44, in Relations 25: 113.

${ }^{61}$ Father Lalemant pointed to this last reason. See his Relation of the Hurons of 1639, in Relations 17: 125. 
yearning of the sick person's soul, and could be cured by satisfying that yearning. The third kind was caused by witchcraft or a spell that some shaman, or 'sorcier', cast on a person. It could only be cured by exorcising the spell from the patient's body. It was the Innu's belief in illness caused by manitou, as well as the Hurons' belief in spells causing illness, that helped the native people to believe in both the healing and killing power of Christianity. ${ }^{62}$

The nomadic peoples, to begin with, interpreted God's power to control epidemics and deaths from their traditional shamanistic perspectives. The people feared powerful shamans whom they believed to kill people by charms or imprecations made to the manitou. The traditional idea that the manitou had power to control illness helped the nomadic peoples near the French settlements to suspect that God, or the Christian 'manitou', had the same power. Also, their identification of the Jesuits with shamans enhanced the idea that the priests could save the sick as did native healing shamans who were traditionally believed to communicate with manitou. When the Algonquin people in Trois-Rivières accused the missionaries of causing serious illness by witchcraft in 1638-39, they began to rely on Christian sacraments and to ask for the Eucharist to save them. This was because native shamans claimed that their communication with the manitou was unable to cure their patients infected with strong European diseases. It was also because the people attributed illness to the priests rather than to their traditional shamanism. Once the indigenous people regarded God as the Christian manitou that caused disease and death, they thought that only God, as well as the priests' manitou, could control their lives. ${ }^{63}$

The Huron people, too, had their own notions of disease and death, which were applicable to the understanding of God as the arbiter of life. Two kinds of shamans were in charge of healing. One kind, called 'ocata' or 'saokata', diagnosed the nature of a disease. The other was an apothecary called 'ontetsans' or 'aretsans', who treated illnesses. From another standpoint, healing shamans were called 'arendiwane', meaning one whose supernatural power is great, and 'oki', metaphorically

${ }^{62}$ Le Jeune's Relation of 1634 \& 1636, in Relations 7: 181; \& 9: 81, 209-11; and Ragueneau's Relation of the Hurons of 1647-48, in Relations 33: 199.

${ }^{63}$ Le Jeune's Relation of 1633, 1636, 1637 and 1639, in Relations 5: 233-39; 8: 271-73; 9: 75-77; 12: 7-9; \& 16: 53-55. The idea of a powerful God may have been enhanced by the fact that the French settlers did not fall sick as easily as the Amerindians and the French patients recovered early. See also Le Jeune's Relation of 1636, in Relations 9: 139-41. 
the same as the powerful spirits in which the Huron people believed. This type of shaman was believed to communicate with the powerful spirit that would either enter his body or appear to him in his dreams and visions. There was a belief that some dangerous shamans, called 'oki ontatechiata', could kill people by spells. In Ossossané, for example, the Jesuits were invited to the preparation for a healing ritual in 1638-39. ${ }^{64}$ In this indigenous conceptual framework, the Hurons understood God as the Christian oki and the Jesuits as shamans who could cure and kill with the help of oki.

For those Amerindians whose first motive for baptism was to survive illness, however, requesting healing from God through the priests meant that it was specifically for curative purposes and for nothing else. Father Le Jeune admitted that, even though the Innu and Algonquin people sought curative help from the missionaries, those who recovered their health ceased to follow other religious advice provided by the evangelists. This was also the case with the Hurons. Father Lalemant criticised the fact that most ailing villagers in the country sought baptism only for survival and, on their recovery from illness, ceased to obey the Jesuits. ${ }^{65}$

The missionaries were just as responsible as the Amerindians for creating a link between their faith and death or recovery in an indigenous way. First of all, as the Iberian missionaries had done to Japanese Buddhist and Shintô priests, the priests attempted to criticise native shamans and increase their own reputation as powerful shamans. They used their scientific knowledge and Christian prayers, mentioned above, at every opportunity to impress people. In 1637, Father Le Jeune noted that he and his brethren were considered to be 'Manitousisiouekhi', which meant those who were superior to men because of their acquaintance with manitou. By the early 1640s, Father Brébeufs reputation as a powerful shaman was widespread, even beyond Huronia, among the neighbouring Atiwandaronk, or the Neutral people. ${ }^{66}$

It was also the missionaries who presented the idea of accepting Christianity as the method to prevent the outbreak of disease. According to Father Le Mercier in the Relation of 1637, Father Brébeuf was

${ }^{64}$ J. Lalemant's Relation of 1639, in Relations 17: 165-75 \& 211-13; Ragueneau's Relation of 1648, in Relations 33: 193 \& 219-21. For the meaning of arendiwane, see Tooker, op. cit., 91 \& note 76.

${ }^{65}$ Le Leune's Relation of 1637, in Relations 11: 149-83; and J. Lalemant's Relation of the Hurons of 1642 and 1644-45, in Relations 23: 117-19; 28: 39-41 \& 77.

${ }^{66}$ Le Jeune's Relation of 1637, in Relations 11: 257-59; and J. Lalemant's Relation of 1640-41, in Relations 21: 207-09. 
invited to a council of Ossossané, which asked him for help in preventing disease. Of the several conditions for help he proposed to the council, the first and most important was to believe in God and keep His commandments. ${ }^{67}$

Furthermore, the healing sacraments by the priests and their occasional ineffectiveness increased imaginary association with killing ceremonies. Healing was accompanied by a crucifix and sacred water. The great majority of people who received baptism or other rituals were those, including children, who were extremely ill, especially in Huronia and surrounding regions. The patients were infected with unfamiliar European diseases and thus needed medical care or at least nursing. The Christian healing sacraments never stopped the epidemics even in Ihonatiria, a village where the missionaries founded the first missionary station in Huronia. One should remember that, because this village later disappeared, after the steep decline of population, the priests had to relocate their station to another village of Ossossané ${ }^{68}$

\section{Benefits through Religious Objects}

The native converts treasured religious objects used for Christian sacraments, just as the Japanese neophytes and the Europeans had done. Such items included medals, rosaries, crucifixes, sacred relics and holy water. According to Father Le Jeune as early as 1638, sacred water grew in repute as a curative means among the Amerindians in Sillery. Crucifixes and rosaries also became treasured items among the Christians in this réduction by the early 1640s. Also in 1647, a Christian headman in this settlement held a crucifix and a rosary with a medal in order to harangue his people for combat. This chief may have intended to raise morale or to achieve a victory through these items, or both. In 1639, Father Le Jeune described an Algonquin man who hung a rosary around his ill child's neck for God's healing. Attikamègue women also hung a rosary around their little children's necks for God's protection in 1647-48. Father Lalemant wrote from Quebec in the Relation of 1646 that indigenous Christians, who stayed somewhere near Quebec

${ }^{67}$ Le Mercier's Relation of 1637, in Relations 13: 169-71.

${ }^{68}$ Le Mercier's Relation of the Hurons of 1637, in Relations 13: 165; and Lalemant's Relations of the Hurons of 1640 and 1640-41, in Relations 19: 129-31; \& 21: 233; and Joseph-Marie Chaumonot's letter to Philippe Nappi, Supérior de la Maison Profess, at Rome, from the Huron country, 26 May 1640, in Relations 18: 25-27. 
or Trois-Rivières, wore religious tools imported from France for healing illness and the safe delivery of babies. ${ }^{69}$

The Amerindians were already culturally predisposed to accepting Christian rewards from the use of amulets. In effect, these native peoples had already kept charms for worldly benefits. In 1635-36, Father Le Jeune learnt that the native Innu or Algonquin people around the French settlements, albeit not all, carried some article prescribed by the manitou for health and longevity. In 1642, an indigenous resident of Sillery kept a special stone that he believed would bring, with the help of the manitou, good fortune or success in hunting and warfare. That was the kind of stone, like a gallstone, that was found in internal organs, like a heart or a throat, of such game as elks or moose. ${ }^{70}$

The Jesuits discoursed Huron amulets in great detail. According to Fathers François du Péron and Jérôme Lalemant, all or nearly all the Huron people had amulets that were believed to bring them desired success or benefits. Father Ragueneau noted that the charms were stones or snakes. The people believed that they would be lucky with the amulets during hunting, fishing, trading and gambling. They believed especially in the effect of 'onniont', a kind of serpent in the shape of an armoured fish that was bartered at a high price from the Algonquin. In 1639, Father Lalemant referred to the deep attachment to amulets even among those who were baptised. ${ }^{71}$

Yet it was the missionaries who introduced to the Amerindians the physical tokens of the Christian faith as effective amulets. The missionaries let their patients drink the holy water or poured it over the afflicted parts of their bodies in the hope of healing them. In Huronia, the missionaries hung a crucifix before the entrance of their dwelling and another on top of it so that God might preserve them from any malady. In 1636, the missionaries applied a 'Relic of Our Blessed Father St. Ignatius' to a Huron woman for the safe delivery of her baby. In 1637, Father Brébeuf explained to his Huron host that holy

${ }^{69}$ Le Jeune's Relations of 1638 and 1639, in Relations 14: 223; \& 16: 47; Vimont's Relations of 1642-43 and 1643-44, in Relations 24: 91-93; \& 25: 187-89; and J. Lalemant's Relations of 1645-46, 1647 and 1647-48, in Relations 29: 197-99; 31: 17375; \& 32: 287.

${ }^{70}$ Le Jeune's Relations of 1636 and 1637, in Relations 9: 119-21; \& 12: 13-15; and Vimont's Relation of 1642, in Relations 22: 95.

${ }^{71}$ François du Péron's letter to Joseph-Imbert du Péron, from Ossossané, 27 April 1639, in Relations 15: 181; J. Lalemant's Relation of the Hurons of 1639, in Relations 17: 211; and Ragueneau's Relation of the Hurons of 1647-48, in Relations 33: 211-15. 
water served to drive away the devils. In Tadoussac in 1642-43, Father Jean de Quen told a non-Christian Innu to discard his native amulets, including his special pouch containing a traditional charm, that he was using to try to save his stricken son. The priest instead suspended a crucifix above the head of the child for its healing effect. ${ }^{72}$ Yet, considering this last incident along with the amulets found in Sillery and the Huron converts' retention of traditional charms, the Christian amulets do not seem to have fully replaced the native ones.

\section{Conclusion}

In order to to understand how former non-Christians accepted and practised Christianity, one should not focus on the individuals' depth of belief or on the resemblance to the European Christian belief. It is more important to study how the people used their limited comprehension based on their conventional non-Christian concepts to digest what the foreign missionaries preached as Christianity. This religious practice should be treated collectively rather than individually. For this, the case study of Japan provides a typical example of how nonChristians accepted Christian belief and practice, and this case study can be applied to the Amerindian conversion to Christianity.

For a people without a Euro-Christian cultural background, Jesuit preaching and Christianity were understood within the context of their own traditional non-Christian culture. This was certainly the case with both the Japanese and the Amerindians. What Christianity meant to these peoples was exactly what the missionaries presented to them, not only in Christian instruction but also in evangelistic activity. Beyond a purely religious framework, the missionary work in Japan and New France helped converts to replace existing social ties, to imagine access to worldly benefits, to seek healing from the faith and even to imagine spiritual power in Christian items. That was not a simplistic process of replacing non-European religions with Christianity in such a way as Cushner proposes. ${ }^{73}$

72 Brébeuf s Relation of the Hurons of 1636, in Relations 10: 73; Le Mercier's Relation of 1637, in Relations 13: 233; \& 14: 37-39; Vimont's Relation of 1642-43, in Relations 24: 21-23 \& 133-35; and J. Lalemant's Relation of 1647, in Relations 31: 197-99.

${ }^{73}$ Cf. Cushner, op. cit., 3-4 \& 198. 
As was the case with the Iberian predecessors, the French missionaries took full advantage of the native concepts that were useful for their evangelisation. This attitude in the missionary approach was the primary determinant for creating the Christian faith among the Japanese and the Amerindians. As with the Japanese, the indigenous people in New France developed what they imagined to be the Jesuit version of Christianity, both under the direction of priests and in their own native terms.

Subsequently in New France, Christianity united the native people socially, enabled them to gain access to social services and worldly benefits, and raised expectations of healing by means of Christian amulets. Yet these spiritual elements were not the indigenous people's conscious adaptation of the Christian messages. ${ }^{74}$ They were more likely to have been the natural responses to the Jesuit preaching in native terms that inevitably used analogies to Amerindian cultural aspects. The evangelistic efforts invoked associations between Christianity and worldly shamanistic benefits. The preaching method that the missionaries adopted for explaining Christianity in a way comprehensible to indigenous people was the most instrumental in creating an indigenous version of Christianity.

Thus, in both Japan and New France, there was a vast gulf between the Jesuits' appraisal of non-European converts and the non-Europeans' practice of Christianity. From the Jesuit point of view which can be seen in Jesuit propaganda contained in their correspondence, their success in transforming non-Christian people into pious Christians was never in doubt. Conversely, from the Japanese or Amerindian point of view, which can be read between the lines of the priests' observations of non-European culture, there was a strong association with non-Christian spiritual customs-including Buddhism, Shintô, and shamanism-in applying Christian ideas and in understanding the behaviour of the priests. This native perspective really meant that Christianity was only accepted and understood in terms of the deeprooted customs and beliefs of both the Japanese and Amerindians.

${ }^{74}$ Cf. Blackburn, op. cit., 105-139. 